\title{
Activation of NF-кB by Adherent Pseudomonas aeruginosa in Normal and Cystic Fibrosis Respiratory Epithelial Cells
}

\author{
E. DiMango, ${ }^{\star}$ A.J. Ratner, R. Bryan, S. Tabibi, and A. Prince \\ *Department of Medicine and Department of Pediatrics, College of Physicians and Surgeons, Columbia University, New York 10032
}

\begin{abstract}
PMN-dominated airway inflammation is a major component of cystic fibrosis (CF) lung disease. Epithelial cells respond to organisms such as Pseudomonas aeruginosa, the major pathogen in CF, by expressing the leukocyte chemokine IL-8. Experiments were performed using several different types of respiratory epithelial cells that demonstrate that ligation of ceramide-associated receptors on epithelial surfaces by $P$. aeruginosa pili is a major stimulus for the translocation of transcription factor nuclear factor (NF)- $\kappa B$ and initiation of IL-8 expression by epithelial cells. Using electrophoretic mobility shift assays and Western hybridizations, nuclear NF- $\kappa$ B was found shortly after epithelial cells were stimulated by either whole organisms, isolated pili, or antibody to the pilin receptor asialoGM1. IB3 cells, which express mutations in cystic fibrosis transmembrane conductance regulator (CFTR) $(\Delta \mathrm{F} 508 / \mathrm{W} 1282 \mathrm{X})$, were noted to have significantly greater amounts of endogenous nuclear $\mathrm{NF}-\kappa \mathrm{B}$, but not the transcription factor $\mathrm{C} / \mathrm{EBP}$, than $\mathrm{CF}$ cells corrected by episomal copies of normal CFTR (C-38) or IB3 cells grown at a permissive temperature $\left(25^{\circ} \mathrm{C}\right)$. Activation of NF- $\kappa$ B and subsequent IL-8 expression in epithelial cells can result from activation of at least two pathways: an exogenous signaling cascade that is activated by ligation of ceramide-associated adhesins such as $P$. aeruginos $a$ pilin, or endogenous stimulation, suggested to be a consequence of cell stress caused by the accumulation of mutant CFTR in the endoplasmic reticulum. (J. Clin. Invest. 1998. 101:25982605.) Key words: Pseudomonas aeruginosa - cystic fibrosis • nuclear factor $\kappa \mathrm{B} \cdot$ pilin - cystic fibrosis transmembrane conductance regulator
\end{abstract}

\section{Introduction}

Mucosal surfaces are highly adapted to mediate interactions between the host and pathogenic microorganisms. Multiple innate and immunologically based mechanisms exist to prevent inadvertently inspired bacteria from reaching the epithelial surface. These defenses include the mucociliary escalator, the activity of antimicrobial peptides in the airway surface fluid,

Address correspondence to Dr. Alice Prince, Columbia University, College of Physicians and Surgeons, $650 \mathrm{~W}$. 168th Street, New York, NY 10032. Phone: 212-305-4193; FAX: 212-305-2284; E-mail: asp7@ columbia.edu

Received for publication 21 January 1998 and accepted in revised form 1 April 1998.

J. Clin. Invest.

(C) The American Society for Clinical Investigation, Inc. 0021-9738/98/06/2598/08 \$2.00

Volume 101, Number 11, June 1998, 2598-2606

http://www.jci.org and local antibody and phagocytic cells. The few organisms that are not entrapped by mucin or lysed by defensins and lysozyme must penetrate the glycocalyx barrier to gain access to the epithelial surface itself. Although many organisms may be able to recognize epithelial glycolipid receptors in vitro (1), few organisms can broach the mucosal defenses to find the available binding sites present in vivo.

In several pathological conditions and particularly in cystic fibrosis $(\mathrm{CF}),{ }^{1}$ there is a relative failure of the shielding of the epithelial surface from bacteria. Diminished defensin activity within the milieu of the CF airway surface fluid $(2,3)$ and the increased number of asialoglycolipid receptors on cells with cystic fibrosis transmembrane conductance regulator (CFTR) mutations provide increased opportunities for bacteria that express the necessary adhesins to bind to the cells lining the mucosa (4). Epithelial cells respond to these adherent organisms with the expression of the PMN chemokine IL-8 (5). Neutrophil-dominated inflammation is a major component of the airway disease in CF and numerous clinical studies demonstrate high levels of IL-8 in the airways of CF patients at virtually all stages of the disease (6-10). Young infants with CF, even in the absence of clinically apparent lung disease, have excessive production of proinflammatory cytokines both in response to bacterial pathogens (9) and in the absence of detectable infection (10).

The major pathogen in CF is Pseudomonas aeruginosa, a ubiquitous organism rarely associated with infection in normal hosts. An efficient opportunist, $P$. aeruginosa can occasionally persist in the airway, due to its ability to express a large number of virulence factors and relative resistance to host defense mechanisms, particularly in the milieu of the CF lung (2). Inhaled $P$. aeruginosa usually express pili and flagella that can function as ligands for asialylated receptors $(4,11)$, found in increased number in CF cells $(12,13)$. Ligation of the GalNAc $c_{\beta 1-4}$ Gal moiety exposed on ceramide-associated glycosphingolipids, such as asialoGM1, by either piliated organisms or by the isolated gene products pilin and flagellin, stimulates the expression of IL- 8 by the epithelial cell (5). This response is at the level of IL-8 gene transcription. In several types of cells, IL-8 expression is elicited by stimuli that cause translocation of the nuclear (transcription) factor (NF)- $\mathrm{B}$ to the nucleus (14). IL-8 transcription is initiated in response to the recognition of $\kappa \mathrm{B}$ sites in the promoter region of the IL- 8 gene by the RelA(p65) component of the NF-кB heterodimer, either by itself, or in concert with additional transcription factors (15). In response to appropriate stimuli IкBs, which are normally complexed with NF-кB, are phosphorylated and targeted for proteolysis. This exposes the nuclear localization sequence and al-

1. Abbreviations used in this paper: CF, cystic fibrosis; CFTR, cystic fibrosis transmembrane conductance regulator; ER, endoplasmic reticulum; NF-кB, nuclear factor $\kappa \mathrm{B}$; TLCK, $N$ - $\alpha$-p-tosyl-L-lysine chloromethyl ketone; TPCK, L-1-tosylamido-2-phenylalanine chloromethyl ketone. 
lows for translocation of NF- $\mathrm{KB}$ to the nucleus and initiation of gene transcription (16).

The ligand-receptor interaction at the surface of the epithelial cell may be sufficient to initiate such proinflammatory signaling cascades, beginning the cycle of inflammation and tissue destruction typical of CF lung disease. The presence of neutrophils and cytokines in the airways of $\mathrm{CF}$ patients, as demonstrated in studies of bronchoalveolar lavage fluid, may represent the attempt to eradicate organisms early in the disease process but a failure to appropriately modulate the inflammatory response. Constitutive activation of $\mathrm{NF}-\kappa \mathrm{B}$ has been recognized as a contributing factor to abnormal cell proliferation in some neoplasms $(17,18)$. Endogenous signals that result in the activation of NF-kB may also be an unexpected consequence of some CFTR mutations. The aberrant trafficking of mutant CFTR and its accumulation in the endoplasmic reticulum (ER) has been suggested to be a stimulus for NF-кB activation (19). The observation that adenovirus mutant proteins, which are targeted to remain in the ER, cause an endogenous stimulus for NF- $\mathrm{BB}$ activation (20) has been suggested to be comparable to the situation in cells with certain classes of CFTR mutations. Misfolded mutant CFTR, which is also targeted for the ER, could overwhelm the normal degradation pathways provoking cell stress activation of NF-кB (20). Varying degrees of endogenous activation of $\mathrm{CF}$ epithelial cells and the increased bacterial access to asialoglycolipid receptors may act together to create the inflammatory milieu characteristic of $\mathrm{CF}$ airway disease.

In the experiments described in this report, we examined how respiratory epithelial cells, both transformed cell lines and cells in primary culture, participate in immune surveillance by studying the activation of NF-кB in response to contact with $P$. aeruginosa. Since this host-pathogen interaction is of major clinical significance in $\mathrm{CF}$, we compared the activation of $\mathrm{NF}-\kappa \mathrm{B}$ in cells with CFTR mutations under control conditions and in response to $P$. aeruginosa.

\section{Methods}

Cell culture. 1HAEo- cells, an SV40-transformed human airway cell line (21), 16HBE cells, SV40-transformed human bronchial epithelial cells (22), and CFTEo- ( $\triangle$ F508 homozygous) tracheal epithelial cells (23) obtained from D. Gruenert (University of California, San Francisco, CA), were grown in DME/Ham's F12 (Sigma, St. Louis, MO) supplemented with $10 \%$ FBS. 9HTEo-, human tracheal epithelial cells obtained from P. Davis (Case Western Reserve University, Cleveland, OH) were grown in DME (24). IB3 cells, an adeno-associated virus-transformed human bronchial epithelial cell line derived from a CF patient $(\Delta \mathrm{F} 508 / \mathrm{W} 1282 \mathrm{X})$, and C-38 cells, the rescued cell line which expresses a plasmid encoded copy of a functional CFTR, obtained from P. Zeitlin (Johns Hopkins University, Baltimore, MD) (25), were grown in LHC-8 media (Biofluids, Rockville, MD) supplemented with $10 \%$ FBS. (The IB3 cells used in these studies contain the empty AAV vector.) Human nasal epithelial cells obtained from nasal polyps and bovine tracheal epithelial cells were isolated using the protease method and grown in primary culture as described previously (26).

Bacterial strains and culture conditions. PAO1, a well characterized, nonmucoid laboratory strain of $P$. aeruginosa was grown in M9 media (5). Aliquots of overnight cultures were suspended in PBS and diluted 10-fold into DME/F12 media before stimulation of epithelial cells. Pilin was isolated from DB2, a hyperpiliated mutant of PAO1, as described previously (5). Chemicals were obtained from Sigma unless otherwise specified.
Bacterial adherence assays. The number of PAO1 that were associated with the epithelial monolayers was determined using previously published methods (4). Organisms were metabolically labeled with $\left[{ }^{35}\right.$ S]methionine (NEN, Boston, MA) and incubated with the monolayers for $60 \mathrm{~min}$. After three PBS washes, the epithelial cells were lysed in SDS and associated scintillations were counted. The number of bacteria associated per well of epithelial cells was then enumerated by determining the number of ${ }^{35} \mathrm{~S}$ scintillations per $\mathrm{CFU}$ of PAO1.

Nuclear extracts. Epithelial cell cultures grown to $70 \%$ confluence in 9-cm tissue culture plates were weaned from 10 to $2 \%$ FBS for $18 \mathrm{~h}$. Cells were stimulated with various agents in DME/F12 media containing $2 \%$ FBS for $1 \mathrm{~h}$, washed, and the nuclei were extracted according to the method of Dignam (27). Stimulants included PAO1 $\left(10^{8} \mathrm{CFU} / \mathrm{ml}\right)$ in DME/F12, purified $P$. aeruginosa $\mathrm{PAO} 1$ pilin $(100 \mu \mathrm{g})$ (4), gel-purified PAO1 flagellin (100 $\mu \mathrm{g})(11)$, antibody/asialoGM1, 1:50 (Wako Bioproducts, Richmond, VA); IL-1 $\beta$ (50 ng/ml), or TNF- $\alpha$ $(0.5 \mathrm{ng} / \mathrm{ml})$. Control wells were tested for cell viability by trypan blue exclusion after manipulation. After stimulation, the cells were washed twice with ice cold PBS, scraped into $1 \mathrm{ml}$ of cold PBS, and centrifuged at $4^{\circ} \mathrm{C}$ for $20 \mathrm{~s}$ in a microcentrifuge. The cell pellet was

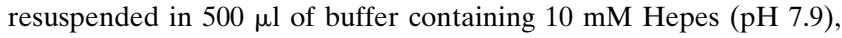
$1.5 \mathrm{mM} \mathrm{MgCl}_{2}, 10 \mathrm{mM} \mathrm{KCl}, 0.5 \mathrm{mM}$ fresh DTT, and the protease inhibitors (0.5 mM PMSF, $1 \mathrm{mM}$ benzamidine hydrochloride, $5 \mu \mathrm{g} / \mathrm{ml}$ aprotinin, and $30 \mu \mathrm{g} / \mathrm{ml}$ leupeptin). The cell pellet suspension was lysed with a Dounce homogenizer, (Kontes Scientific Glassware, Vineland, NJ) and the extent of lysis determined by trypan blue exclusion. The cell lysate/nuclear suspension was obtained by centrifugation $\left(14,000 \mathrm{~g}\right.$ for $2 \mathrm{~min}$ at $4^{\circ} \mathrm{C}$ in a microfuge). The pellet was resuspended in $50 \mu \mathrm{l}$ of buffer composed of $20 \mathrm{mM}$ Hepes ( $\mathrm{pH} 7.9$ ), $25 \%$ glycerol, $0.42 \mathrm{M} \mathrm{NaCl}, 1.5 \mathrm{mM} \mathrm{MgCl}, 0.2 \mathrm{mM}$ EDTA, $0.5 \mathrm{mM}$ DTT, and protease inhibitors, and left on ice for $1 \mathrm{~h}$ with occasional vortexing. Extracted nuclei were isolated by further centrifugation at $14,000 \mathrm{~g}$ for $5 \mathrm{~min}$ at $4^{\circ} \mathrm{C}$. Protein concentration was determined using the method of Bradford (BioRad, Richmond, CA).

Electrophoretic mobility shift assays. Oligonucleotide probes containing the consensus sequence for NF-кB (5'-AGT TGA GGG GAC TTT CCC AGG C-3') (15) were purchased from Santa Cruz Technologies (Santa Cruz, CA). Nuclear extracts $(10 \mu \mathrm{g})$ were incubated with 5,000 cpm of ${ }^{32} \mathrm{P}$ end-labeled oligonucleotide probe, $2 \mu \mathrm{g}$ of salmon sperm DNA, $10 \mathrm{mM}$ Tris ( $\mathrm{pH} 7.5), 50 \mathrm{mM} \mathrm{NaCl}, 5 \%$ glycerol, $1 \mathrm{mM}$ EDTA ( $\mathrm{pH} 8.0$ ), and $0.2 \mathrm{mg} / \mathrm{ml} \mathrm{BSA}$ in a final volume of $20 \mu \mathrm{l}$ for $20 \mathrm{~min}$ at room temperature. For supershift assays, antibody to the p65 or p50 subunits of NF-кB (Santa Cruz Technologies) was added to the reaction mix as well. The complexes were fractionated on $4 \%$ native polyacrylamide gels run in $0.22 \times$ TBE buffer at $4^{\circ} \mathrm{C}$, dried, and exposed to Fuji film at $-70^{\circ} \mathrm{C}$. A C/EBP probe (5'-GAT CGC CTA GCA TTC ATC ACA CGT-3') (28) was obtained from K. Calame (Columbia University, New York).

Immunocytochemistry. 1HAEo- cells were grown to near confluence on glass coverslips in 24-well plates and media replaced with DME/F12 plus $2 \%$ FCS 18 h before study. The cells were stimulated with PAO1 $\left(10^{8} \mathrm{CFU} / \mathrm{ml}\right)$ for $1 \mathrm{~h}$ and then washed with PBS. Cells were fixed with $4 \%$ paraformaldehyde for $20 \mathrm{~min}$ at room temperature, washed with PBS, and blocked in $10 \%$ goat serum plus $0.1 \%$ BSA for $1 \mathrm{~h}$. After blocking, the cells were washed three times in PBS and incubated with a 1:100 dilution of rabbit polyclonal antibody/p65 (Santa Cruz Biotechnologies) for $1 \mathrm{~h}$ at room temperature, washed, and then incubated with goat anti-rabbit IgG conjugated to TRITC (1:50) (Zymed, San Francisco, CA) in PBS plus 0.1\% BSA, plus an equal volume of bis-benzamide $(50 \mu \mathrm{g} / \mathrm{ml})$ for $30 \mathrm{~min}$ at room temperature. Localization of the anti-p65 binding was detected using fluorescence microscopy and bis-benzamide staining was imaged using a 330-380/400-420 nm excitation-transmission filter.

Western hybridization. Epithelial cells grown in six-well plates to $70 \%$ confluence were weaned from 10 to $2 \%$ FBS for $18 \mathrm{~h}$. The epithelial cells were then stimulated under the conditions described for gel shift assays for $1 \mathrm{~h}$, washed, and lysed by the addition of $0.5 \%$ Tri- 


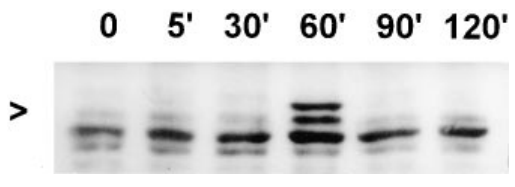

Figure 1. Kinetics of $\mathrm{NF}-\mathrm{\kappa B}$ activation in $16 \mathrm{HBE}-$ cells. Western hybridization using anti-p65 antibody to detect activation of NF- $\mathrm{kB}$

RelA in cell extracts harvested from epithelial monolayers grown in six-well plates at selected time intervals after the addition of $10^{8}$ $\mathrm{CFU} / \mathrm{ml}$ of PAO1 to the cells. The arrow denotes $65 \mathrm{kD}$.

ton X-100 in PBS for $30 \mathrm{~min}$. Aliquots of the cells ( $100 \mu \mathrm{g}$ of lysate by protein concentration) were boiled in Laemmli buffer and the proteins separated by electrophoresis on $10 \%$ SDS-polyacrylamide gels and transferred to nitrocellulose membranes. Membranes were blocked in 5\% skim milk overnight and immunoblotted with affinitypurified rabbit polyclonal antibody to the p65 NF-kB subunit. Immune complexes were detected with goat anti-rabbit IgG conjugated to horseradish peroxidase (Caltag, Burlingame, CA) using electrochemilluminescence.

IL-8 ELISA assays. 1HAEo- cells grown in 96-well microtiter plates were assayed for the production of IL-8 in response to stimulation with $P$. aeruginosa $\mathrm{PAO} 1$ in the presence of different agents expected to inhibit the activation of NF- $\mathrm{KB}$. Confluent monolayers grown in 96-well plates were serum starved for $18 \mathrm{~h}$ and exposed to an aliquot of $10^{7} \mathrm{CFU} / \mathrm{ml}$ of PAO1 (cultured overnight, washed in PBS, and resuspended in DME/F12) for $60 \mathrm{~min}$ at $37^{\circ} \mathrm{C}$. Selected wells were preincubated for $60 \mathrm{~min}$ with dexamethasone $(2-20 \mu \mathrm{M})$, $N$ - $\alpha$ - $p$-tosyl-L-lysine chloromethyl ketone (TLCK) $(10-100 \mu \mathrm{M})$,
L-1-tosylamido-2-phenylalanine chloromethyl ketone (TPCK, 2-50 $\mu \mathrm{M}$, dissolved in DMSO. The monolayers were washed three times with PBS and reincubated with $200 \mu$ l DME/F12 plus gentamicin (100 $\mu \mathrm{g} / \mathrm{ml}$ ), in addition to the above inhibitors, for $4 \mathrm{~h}$. Protein concentrations of the cell lysates were measured using a Micro BCA protein assay kit (Pierce, Rockford, IL). IL-8 in the epithelial supernatants was measured by ELISA using plates coated with human monoclonal anti-IL-8 (R and D Systems, Minneapolis, MN) and detected using polyclonal rabbit anti-human IL-8 (Genzyme, Cambridge, MA) and anti-rabbit IgG conjugated to alkaline phosphatase (Caltag).

Statistical methods. A one-way ANOVA was used to test the null hypothesis that there was no difference in the amount of IL-8 production by epithelial cells treated with dexamethasone, TLCK, or TCPK as compared with cells incubated with PAO1 under control conditions. Each experimental point was performed in triplicate or quadruplicate and a mean and SD were calculated.

\section{Results}

P. aeruginosa PAO1 stimulates the activation of $N F-\kappa B$. A kinetic study was performed to follow the appearance of the p65 subunit of NF- $\mathrm{KB}$ (RelA) in cell lysates after stimulation of 1HAEo- epithelial cells by incubation with $P$. aeruginosa PAO1 (Fig. 1). Confluent monolayers were exposed to an inoculum of $10^{8} \mathrm{CFU} / \mathrm{ml}$ of organisms for increasing amounts of time and cell extracts were screened for the presence of proteins identified using antibody to the p65 component of $\mathrm{NF}-\kappa \mathrm{B}$, available upon cleavage of IкB. $60 \mathrm{~min}$ after exposure to the organism, proteins with mobility equivalent to 68 and 65

\section{I - Control conditions}
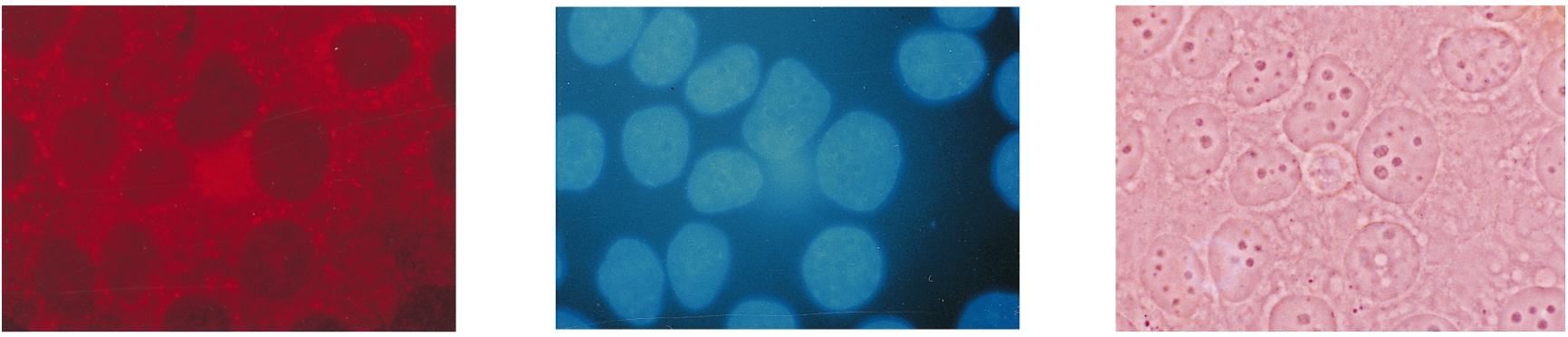

\section{II - 1 hour after exposure to PAO1}
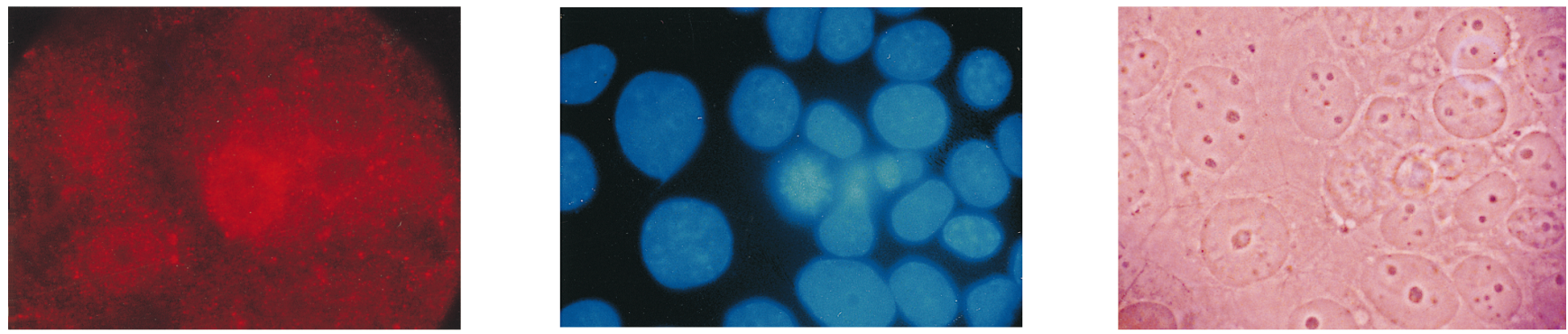

\section{A. anti-NF-kBp65 - TRITC}

B. Bis benzamide nuclear stain

C. Visible light

Figure 2. Immunocytochemical staining of $1 \mathrm{HAEo}-$ cells to localize NF-кBp65: I. control conditions. II. 60 min after the addition of PAO1 to cells grown on coverslips. $(A)$ Fluorescence microscopy of permeabilized cells treated with anti-p65 NF-кB-TRITC. $(B)$ bis-benzamide nuclear stain of the same field visualized under UV illumination. $(C)$ Appearance of the field under visible light. 


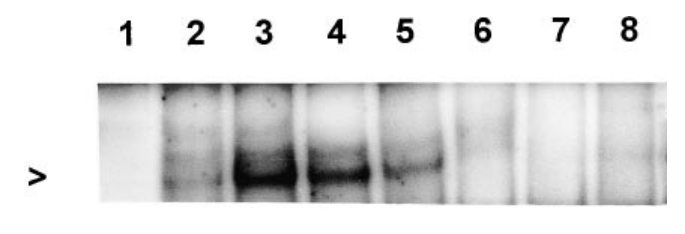

$\begin{array}{lllllllll}\text { IL-1 } \beta & - & - & + & - & - & - & - & + \\ \text { TNF- } \alpha & - & - & - & + & - & - & - & - \\ \text { PAO1 } & - & - & - & - & + & + & + & - \\ \text { anti-p50 } & - & - & - & - & - & + & - & - \\ \text { anti-p65 } & - & - & - & - & - & - & + & +\end{array}$

Figure 3. Electrophoretic mobility gel shift assays using an NF-кB oligonucleotide probe. Nuclear extracts harvested from 9HTEo- tracheal epithelial cells stimulated with IL-1 $\beta$, TNF- $\alpha$, or PAO1 were incubated with a ${ }^{32} \mathrm{P}$-labeled NF-кB oligonucleotide probe. Specificity of the labeled complex is shown in lanes 6-8, in which the nuclear extracts were also incubated with antibody to either the p50 or p65 component of NF-кB. The arrow denotes the NF-кB-specific band.

$\mathrm{kD}$ were identified with antibody to the p65 component of $\mathrm{NF}-\kappa \mathrm{B}$. This result suggests that by $60 \mathrm{~min}$ there is an immunologically detectable amount of the free p65 subunit available in the cell.

Nuclear localization of $N F-\kappa B$ in response to $P$. aeruginosa. The location of NF-кB in human airway epithelial cells was studied by treating cells grown on coverslips with TRITClabeled antibody to the NF-кB p65 subunit under control conditions, and at 30 min intervals after exposure to $P$. aeruginosa (Fig. 2). The distribution of TRITC-tagged NF-кB was entirely cytoplasmic in the unstimulated cells as shown by fluorescence microscopy. Nuclear localization was performed using bis-benzamide viewed under ultraviolet illumination. 60 min after exposure to $P$. aeruginosa, many epithelial cells had nuclear localization of NF-кB. The same field viewed by visible light microscopy demonstrates that the cell architecture is intact and grossly unchanged from that of the control cells. Control cells labeled with the secondary antibody (TRITC goat antirabbit $\mathrm{IgG}$ ) were negative. Time points at 90 and $120 \mathrm{~min}$ showed no further increase in nuclear fluorescence, suggesting that the NF- $\mathrm{B}$ response to $P$. aeruginosa occurred in the first hour after exposure, consistent with the data shown in Fig. 1.

Demonstration of nuclear NF- $\kappa B$ by electrophoretic mobility gel shift assays in primary and transformed epithelial cell lines. Electrophoretic mobility shift experiments were performed to more rigorously test the activation of NF-kB in response to a $P$. aeruginosa stimulus in different cell lines, as well as in primary epithelial cells isolated from fresh bovine trachea. Bovine cells were used to control for the possibility that $\mathrm{NF}-\kappa \mathrm{B}$ activation might be attributed to the viral transformation of the cell line or allergic processes associated with the cultivation of human nasal polyp tissue. Cell lines with minimal endogenous IL-8 expression (1HAEo-), derived from the trachea (9HTEo-), and derived from bronchial cells (16HBE-) were tested in different experiments, as indicated in the figure legends. NF- $\kappa \mathrm{B}$ is activated in immune cells such as macrophages by the proinflammatory cytokines TNF- $\alpha$ and IL-1 $\beta$. The pattern of NF-кB activation in 9HTEo- human bronchial epithelial cells in response to $P$. aeruginosa $\mathrm{PAO} 1$ was di- rectly compared with that in cells stimulated with TNF- $\alpha$ or IL-1 $\beta$. 9HTEo- epithelial cells stimulated with either IL-1 $\beta$ (50 ng/ml), TNF- $\alpha(0.5 \mathrm{ng} / \mathrm{ml})$, or PAO1 $\left(10^{8} \mathrm{CFU} / \mathrm{ml}\right)$ had similarly activated NF- $\mathrm{B}$ as demonstrated by mobility shift studies (Fig. 3). Recognition of the NF-kB binding site on the probe was blocked in the presence of antibody to p65 or p50. No gel shift was observed using a mutant NF- $\mathrm{B}$ probe in which two of the nucleotides comprising the $\kappa \mathrm{B}$ binding site are mutated, and the addition of $100 \times$ unlabeled probe also eliminated the shift (data not shown).

Ligation of epithelial receptors by pilin or antibody to pilin receptors stimulates the activation of $N F-\kappa B$. Epithelial expression of IL-8 can be induced by purified Pseudomonas ligands or antibody to asialoGM1, the pilin receptor. To establish whether recognition of epithelial receptors by an isolated ligand is sufficient to activate NF-кB, we screened for the appearance of nuclear NF-кB in human bronchial epithelial cells incubated for $60 \mathrm{~min}$ with either whole organisms (PAO1), purified pilin (which recognizes asialoGM1), or antibody to asialoGM1 (Fig. 4). Western hybridizations were performed using nuclear extracts as prepared for gel shift experiments. Minimal reactivity to the anti-p65 antibody was detectable in nuclear extracts prepared from unstimulated epithelial cells as compared with significant amounts of nuclear p65 reactive proteins in cells exposed to whole organisms, pilin, or antibody to asialoGM1.

IL-8 expression does not require epithelial ingestion of $P$. aeruginosa. The demonstration that a relatively brief exposure to $P$. aeruginosa ligands is sufficient to activate NF-кB translocation, suggests that internalization or invasion by intact organisms is not required to activate the epithelial cell. Activation of NF-кB in the epithelial cells has been attributed to signaling cascades stimulated by invasive organisms which have been internalized or by LPS-CD14 interactions as described in macrophages $(29,30) . P$. aeruginosa has been suggested to be invasive in vitro after prolonged (3-4 h) incubation with monolayers (31), unlike the briefer exposures sufficient to activate NF- $\mathrm{B}$. Bacterial adherence assays were performed in increasing concentrations of cytochalasin $\mathrm{D}$ to establish the effect of actin-mediated internalization of organisms in activation of signaling pathways (Fig. $5 \mathrm{~A}$ ). Since the activation of NF- $\mathrm{NB}$ is a transient response, we monitored the expression of IL-8 following conditions known to activate $\mathrm{NF}-\kappa \mathrm{B}$. The number of epithelial cell-associated organisms (adherent or internalized) was not diminished using concentrations of cytochalasin D that block the internalization of $>75 \%$ of the organisms by RAW cells (11). The expression of IL-8 under the same conditions described above, was not decreased in the presence of cytochalasin D $(1 \mathrm{mg} / \mathrm{ml})$ (Fig. $5 B)$, nor did cytochalasin D affect the endogenous amount of IL-8 expression in these cells (data not shown). Accordingly, it appears that actin-mediated internalization of either whole organisms

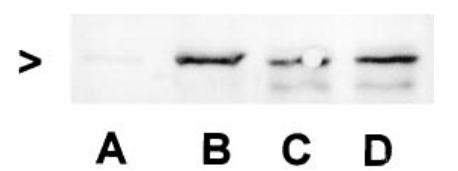

Figure 4. Western hybridization using antibody to NF- $\mathrm{kB}$ p65 to screen nuclear extracts harvested from $16 \mathrm{HBE}-$ human bronchial epithelial cells. $(A)$ Control conditions (unstimulated), or 60 min after incubation with $(B)$ PAO1, $(C)$ purified PAO1 pilin, or $(D)$ antibody to asialoGM1. 
A

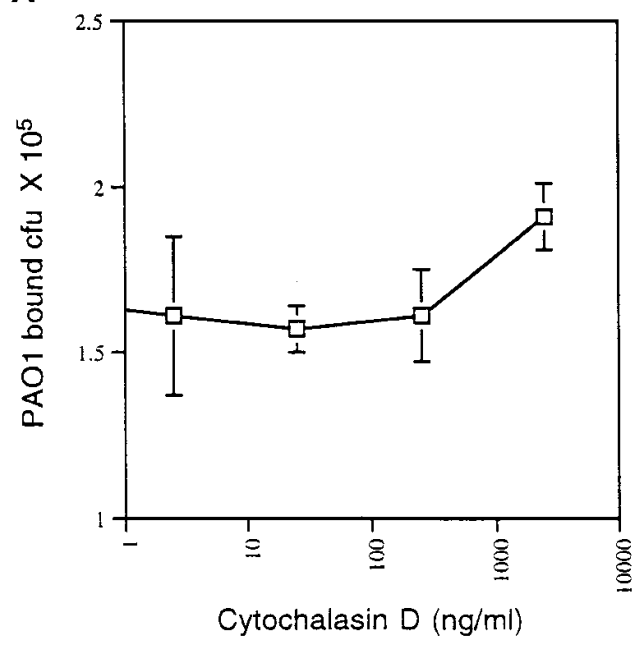

B

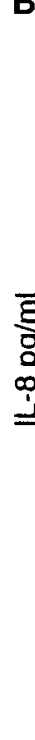

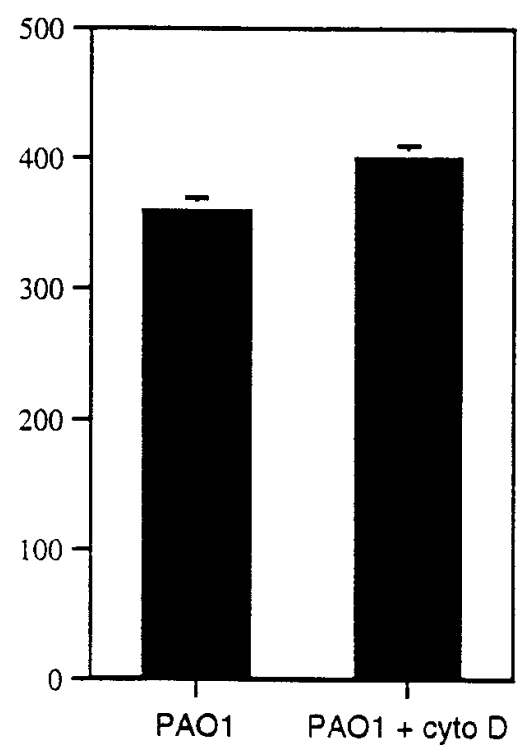

Figure 5. The effect of cytochalasin D on $P$. aeruginosa -epithelial cell interactions and stimulation of IL-8 expression. $(A){ }^{35} \mathrm{~S}$-labeled PAO1 associated with normal human respiratory epithelial cells in primary culture grown from nasal polyp. (B) IL-8 production in cytochalasin D-treated nasal polyp cells. or ligands is not required to stimulate the epithelial IL-8 response.

Protease inhibitors decrease $N F-\kappa B$ activation and the expression of IL-8 in epithelial cells. A prerequisite for the nuclear translocation of NF- $\mathrm{NB}$ is the phosphorylation and proteolysis of the IкBs (32). Compounds that affect the dissociation of the IкB-NF-кB complex by any of several different mechanisms should affect the amount of NF-кB that is free to translocate into the nucleus. Since dissociation of the NF-кBI $\mathrm{B}$ complex is linked to IкB proteolysis, protease inhibitors, by preventing the dissociation of $\mathrm{I} \kappa \mathrm{B}$, prevent the nuclear translocation of NF-кB, and should block the expression of IL-8 (32). The serine protease inhibitor, TPCK completely blocked the nuclear translocation of NF-кB in the tracheal epithelial cells in primary culture (Fig. 6). The effect of TPCK and the inhibitor of chymotrypsin-like activity, TLCK, were also tested by measuring IL- 8 production as stimulated by PAO1 on 1HAEo- cells in the presence of increasing doses of the protease inhibitors (Fig. 7). Both protease inhibitors significantly inhibited the IL- 8 response for all conditions, except the lowest dose of TLCK, without affecting epithelial cell viability, as $<5 \%$ of the cells became permeable to trypan blue.

Dexamethasone can also act to decrease nuclear transloca-

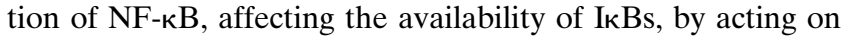

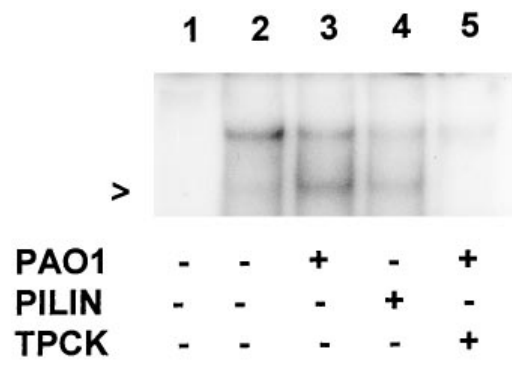

Figure 6. Effect of the protease inhibitor TPCK on the activation of NF-кB. Nuclear extracts obtained from bovine tracheal cells stimulated with PAO1, purified pilin under control conditions, or treated with TPCK were incubated with the NF- $\mathrm{kB}$ oligonucleotide probe in a gel shift assay.
IкB transcription $(33,34)$, or through other mechanisms (35). We tested the effect of dexamethasone on IL-8 expression (Fig. 7) and on the activation of NF-кB using gel shift assays (Fig. 8). IL-8 expression by $1 \mathrm{HAEo}-$ cells was significantly diminished $(P<0.001)$ in cells pretreated with dexamethasone. As predicted, gel shift studies performed using nuclear extracts obtained from 1HAEo- cells demonstrated less nuclear $\mathrm{NF}-\kappa \mathrm{B}$.

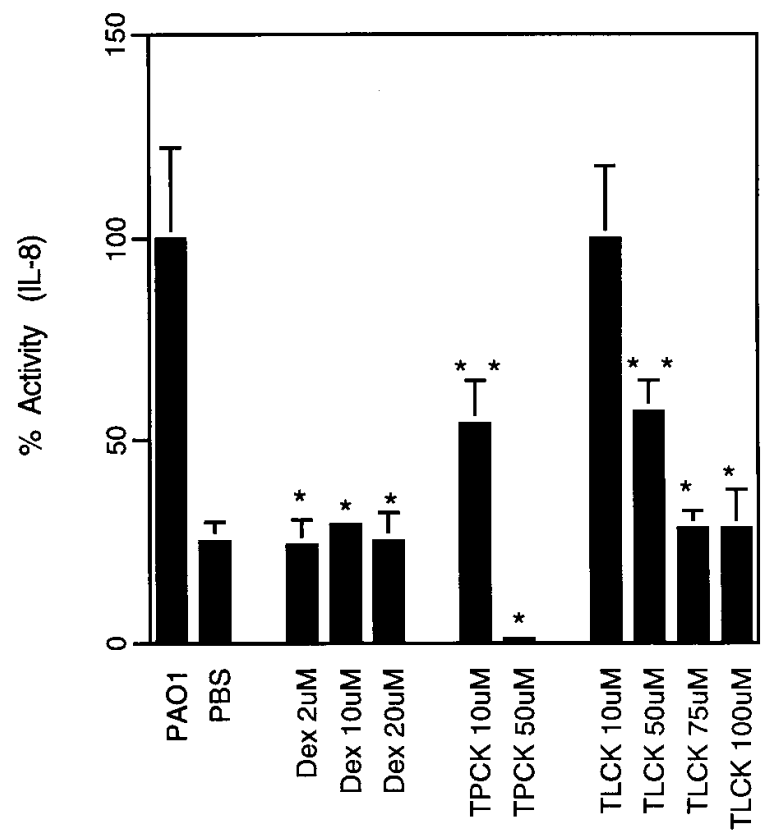

Figure 7. IL-8 expression from cells treated with agents which affect the dissociation of the NF-кB-IкB complex. 1HAEo- cells were stimulated with PAO1 for 60 min under control conditions, in the presence of increasing concentrations of dexamethasone (Dex), or the protease inhibitors TPCK or TLCK. IL- 8 in the cell supernatants was measured by ELISA and standardized by protein content. (**indicates $* * P<0.01, * P<0.001$.) 


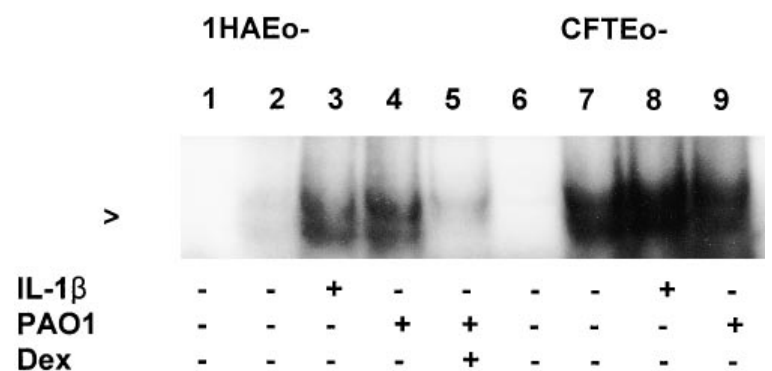

Figure 8. NF-кB activation in 1HAEo- and CFTEo- cells. Gel shift assay to detect the activation of NF-кB in nuclear extracts obtained from 1HAEo- cells (lanes 1-5) stimulated with IL-1 $\beta$ (positive control), PAO1, or PAO1 in the presence of $20 \mu \mathrm{M}$ dexamethasone or CFTEo - cells ( $\Delta$ F508 homozygous) (lanes 7-9). Lanes 1 and 6 contain the probe alone without any nuclear extract; lanes 2 and 7 contain nuclear extracts from unstimulated cells. The other lanes contain nuclear extracts from cells stimulated as indicated. As these are entirely different cell lines, lanes should be compared to each internal, unstimulated control.

Activation of $N F-\kappa B$ in $C F$ cells. In testing the effect of dexamethasone on amounts of nuclear NF- $\mathrm{B}$, we noted that a $\mathrm{CF}$ cell line, homozygous for the $\Delta \mathrm{F} 508$ mutation, had large amounts of endogenous nuclear NF- $\mathrm{B}$ in nuclear extracts harvested from unstimulated cells (Fig. 8). It was difficult to determine if dexamethasone had any effect on the activation of NF-кB in the CFTEo- cells by gel shift assay (data not shown). The increased amount of nuclear NF-kB found in the $\Delta$ F508 cells was consistent with the prediction made by Bauerle that cells expressing mutant CFTR would have an endogenous signal for the activation of NF-кB (19). However, since the $1 \mathrm{HAEO}-$ and $\mathrm{CFTEO}-$ cell lines are entirely unrelated, we performed a similar gel shift study using the isogenic CF (IB3) and corrected C-38 cell lines (25) (Fig. 9). Since the $\Delta$ F508 mutation is temperature-sensitive (36), we postulated that growing the IB3 cells at the permissive temperature should increase the amount of normal trafficking of the mutant protein and decrease the putative stimulus for endogenous signal for NF- $\mathrm{KB}$ translocation.

Under control (unstimulated) conditions, there was minimal nuclear NF- $\mathrm{BB}$ present in the $\mathrm{C}-38$ cells (corrected) grown at $37^{\circ} \mathrm{C}$ (Fig. $9 \mathrm{~A}$, lane 2 ) and even less apparent in nuclear extracts harvested from cells grown at $25^{\circ} \mathrm{C}$ (Fig. $9 A$, lane 5).
Figure 10. C/EBP activity in IB3 cells. Nuclear extracts from the same IB3 cells grown at $37^{\circ} \mathrm{C}$ shown in Fig. 9 were incubated with a $\mathrm{C} / \mathrm{EBP}$ oligonucleotide probe. Lane 1, probe alone; lane 2 , extracts from unstimulated cells; lanes $3-5$, stimulated cells as indicated.

More nuclear NF-кB was apparent after stimulation of the cells with either IL-1 $\beta$ or PAO1. Nuclear extracts prepared from IB3 (CF) cells had greater amounts of NF-kB under the control conditions (Fig. $9 \mathrm{~B}$, lane 2 ) and were stimulated by IL-1 $\beta$ or PAO1 (Fig. $9 \mathrm{~B}$, lanes 3 and 4 ). IB3 cells grown at $25^{\circ} \mathrm{C}$ had less endogenous NF-кB and showed a greater response to both PAO1 and IL-1 $\beta$. As a control, the same nuclear extracts from the IB3 cells $\left(37^{\circ}\right)$ were incubated with a $\mathrm{C} / \mathrm{EBP}$ probe (Fig. 10), which is not activated by retained proteins in the ER (20). The gel shift using the C/EBP probe detected no endogenous $\mathrm{C} / \mathrm{EBP}$ in nuclear extracts, but a significant gel shift was observed after cells were stimulated by either PAO1 or IL-1 $\beta$. The activation of this transcription factor was also somewhat diminished by pretreatment of the IB3 cells with dexamethasone, as has been noted in other cell types (37).

\section{Discussion}

The epithelial cells lining the airway mucosa have an important immunological function in signaling the presence of pathogenic bacteria. Pilin mediated $P$. aeruginosa attachment to these epithelial cells is sufficient stimulus to activate translocation of NF- $\mathrm{BB}$ and subsequent synthesis of IL-8. Respiratory epithelial cells of several different types (human transformed cell lines from trachea or bronchi, and nasal and tracheal epithelial cells in primary culture) responded briskly to adherent $P$. aeruginosa with activation of $\mathrm{NF}-\kappa \mathrm{B}$ detectable within 30 min of exposure. Respiratory epithelial cells appear to have a relatively low threshold for activation of immune surveillance function, and may respond to different types of stimuli than epithelial cells lining other mucosal surfaces or professional immune cells. As opposed to the epithelial cells lining the gas-

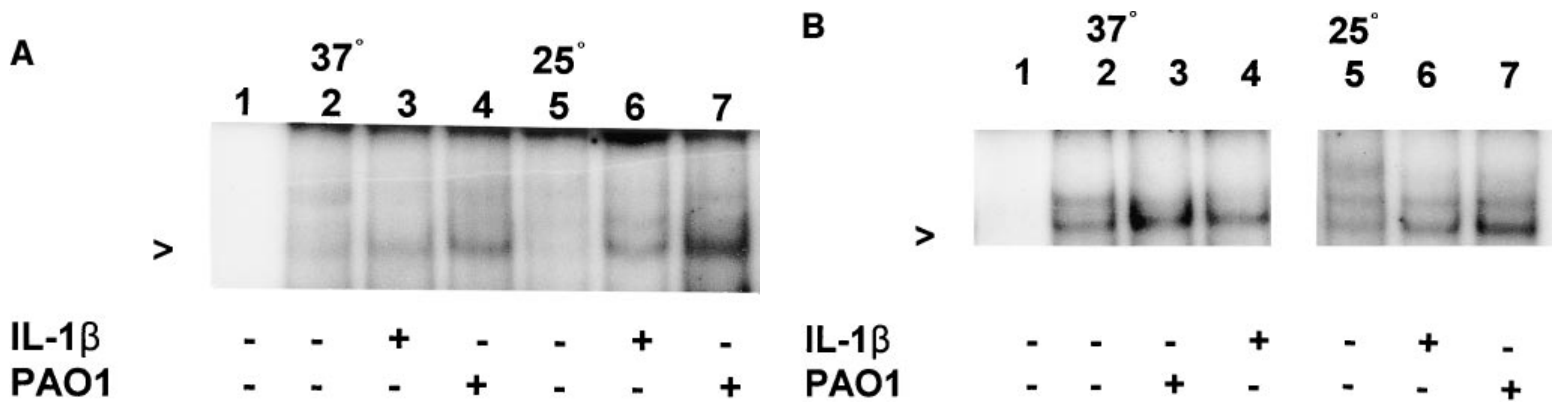

Figure 9. A comparison of NF-кB activation in IB3 (CF) and C-38 (corrected) cells. Gel shift assays performed with nuclear extracts obtained from: $(A) \mathrm{C}-38$ cells or $(B) \mathrm{IB} 3$ cells, grown at $37^{\circ} \mathrm{C}$ (lanes $2-4$ ) or $25^{\circ} \mathrm{C}$ (lanes 5-7). Lane 1 is a control with probe alone, lanes 2 and 5 are from unstimulated cells. 
trointestinal tract, neither internalization of organisms nor polymerization of actin were required for cell activation (38). A much briefer exposure to bacteria than that required for invasion of the epithelial cells was sufficient to activate NF- $\mathrm{B}$ $(31,39)$, and cytochalasin D did not decrease either the number of bacteria associated with the epithelial monolayers, or the amount of IL-8 expressed. Superficial interactions between Neisseria gonorrhea and epithelial cells are also reported to be sufficient to activate NF-кB. Neisseria, like P. aeruginosa, express type IV $N$-methylphenylalanine pili that bind glycolipid receptors on HeLa cells and induce the expression of proinflammatory cytokines including IL-8, by the activation of $\mathrm{NF}-\kappa \mathrm{B}$, even in the presence of cytochalasin D (40). Piliated Escherichia coli similarly stimulate IL-8 expression by uroepithelial cells, a process that requires only adherence to the $\mathrm{Gal}_{1-4} \mathrm{Gal}$ oligosaccharide moiety of the glycosphingolipid receptor on the epithelial cell (41). Thus, the epithelial response to $P$. aeruginosa seems to be typical of several bacterial ligandreceptor interactions at mucosal surfaces.

The signaling cascade that is activated by PAO1 adherence to the respiratory epithelial cell may share components with that evoked by the binding of TNF- $\alpha$, which stimulates a ceramide-activated signaling cascade (14). The kinetics of epithelial activation either by TNF- $\alpha$ or PAO1 were similar. However, the respiratory epithelial cell, unlike the macrophage, does not appear to be responsive to bacterial LPS. LPS derived from either $P$. aeruginosa or $E$. coli does not evoke an IL-8 response in these cells (5) and the activation of NF- $\mathrm{KB}$ described in these experiments occurred entirely in the absence of LPS. The pathway stimulated by adherent Pseudomonas pilin also differs from that which evokes MUC-2 transcription in respiratory epithelial cells in response to $P$. aeruginosa LPS (42). Activation of a ceramide signaling pathway is elicited by binding of P-fimbriated E. coli to glycolipid receptors expressed on the kidney A498 cell line (41). Ligation of Pseudomonas pilin to the gangliotetraoxylceramide receptors, available on epithelial cells, particularly those with diminished sialylation, may also stimulate this pathway (43).

The activation of epithelial cells by superficial contact with $P$. aeruginosa is a likely explanation for the increased inflammatory response observed in CF patients with airway infection as compared with control subjects (9). In animal models of infection, the airways of CF mice respond with significantly greater amounts of inflammation when exposed to the same bacterial inoculum as do normal isogenic controls (44). This increased inflammation may be at least partially ascribed to the increased numbers of asialoGM1 receptors for $P$. aeruginosa binding on cells with CFTR mutations, including the IB3 cells reported herein, and consequently cells with CFTR mutations are more readily stimulated to produce IL-8 (5). However, it was also noted that IL-8 production from unstimulated IB3 cells $(1,200 \mathrm{pg} / \mathrm{ml})$ was consistently higher than from unstimulated C-38 cells $(400 \mathrm{pg} / \mathrm{ml})$ grown under identical conditions (DiMango, E., unpublished data), although the possible significance of this difference was not appreciated at that time.

A perplexing problem has been the recognition that many CF patients, even in the absence of clinical lung disease or detectable infection, have excessive airway inflammation (10). The unexpected finding of significant amounts of constitutively activated NF-KB in the CF cell lines described in this report suggests that mutant CFTR may affect the endogenous amounts of proinflammatory cytokine expression. Constitutive
NF-кB-RelA activation has recently been associated with abnormal cell proliferation in breast cancers (17) and in Hodgkin's disease (18). Failure to regulate this transcription factor appropriately can affect multiple types of cell proliferation responses. Our experimental data are consistent with the prediction that accumulation of mutant CFTR in the ER would be sufficient to stimulate the translocation of NF- $\mathrm{B}$ (20). The observation that endogenous activation of transcription factors in cells with CFTR mutations was not a global response, but limited to NF- $\mathrm{B}$ was also anticipated by these published reports using adenovirus mutant proteins engineered to accumulate in the ER. Partial correction of the $\mathrm{NF}-\kappa \mathrm{B}$ response, by growth of the $\mathrm{CF}$ cells at a permissive temperature to increase the normal trafficking of the mutant protein, provides further support for this hypothesis. More detailed studies of different classes of CFTR mutations and their association with endogenous activation of $\mathrm{NF}-\mathrm{kB}$ are in progress to establish if there is a causal role for certain CFTR mutations in stimulating inflammation in the respiratory tract, even in the absence of definable stimuli. Our data provide more direct evidence to support clinical studies of immunomodulation strategies, along with gene therapy and novel uses of antimicrobial agents, to limit access of $P$. aeruginosa to epithelial receptors to prevent the development of airway inflammation. It may be possible to modulate the proinflammatory activity of the CF respiratory epithelial cell without compromising the normal immune surveillance function of the mucosal barrier.

\section{Acknowledgments}

The authors wish to thank Kathryn Calame and Demetrios Thanos for assistance with the gel shift experiments.

This study was supported by the National Institutes of Health grant DK-39693 (A. Ratner), the Cystic Fibrosis Foundation (A. Prince, E. DiMango, R. Bryan, and A. Ratner), and the Parker B. Francis Foundation (E. DiMango).

\section{References}

1. Krivan, H.C., D.D. Roberts, and V. Ginsburg. 1988. Many pulmonary pathogenic bacteria bind specifically to the carbohydrate sequence GalNAc $\beta 1$ 4Gal found in some glycolipids. Proc. Natl. Acad. Sci. USA. 85:6157-6161.

2. Smith, J.J., S.M. Travis, E.P. Greenberg, and M.J. Welsh. 1996. Cystic fibrosis airway epithelia fail to kill bacteria because of abnormal airway surface fluid. Cell. 85:229-236.

3. Goldman, M.J., G.M. Anderson, E.D. Stolzenberg, U.P. Kair, M. Zasloff, and J.M. Wilson. 1997. Human $\beta$-defensin-1 is a salt-inactivated antibiotic in lung that is inactivated in cystic fibrosis. Cell. 88:553-560.

4. Saiman, L., and A. Prince. 1993. Pseudomonas aeruginosa pili bind to asialoGM1 which is increased on the surface of cystic fibrosis epithelial cells. $J$. Clin. Invest. 92:1875-1880.

5. DiMango, E., H.J. Zar, R. Bryan, and A. Prince. 1995. Diverse Pseudomonas aeruginosa gene products stimulate respiratory epithelial cells to produce interleukin-8. J. Clin. Invest. 96:2204-2210.

6. Standiford, T.J., S.L. Kunkel, M.A. Basha, S.W. Chensue, J.P. Lynch, B. Toews, J. Westwick, and R.M. Strieter. 1990. Interleukin-8 gene expression by a pulmonary epithelial cell line. J. Clin. Invest. 86:1945-1953.

7. Bonfield, T.L., J.R. Panuska, M.W. Konstan, K.A. Hilliard, J.B. Hilliard, H. Ghnaim, and M. Berger. 1995. Inflammatory cytokines in cystic fibrosis lungs. Am. J. Respir. Crit. Care Med. 152:2111-2118.

8. Konstan, M.W., K.A. Hilliard, T.M. Norvell, and M. Berger. 1994. Bronchoalveolar lavage findings in cystic fibrosis patients with stable, clinically mild lung disease, suggest ongoing infection and inflammation. Am. J. Respir. Crit. Care Med. 150:448-454.

9. Noah, T.L., H.R. Black, P.W. Cheng, R.E. Wood, and M.W. Leigh. 1997 Nasal and bronchoalveolar lavage fluid cytokines in early cystic fibrosis. $J$. Infect. Dis. 175:638-647.

10. Khan, T.Z., M.M.K. Gillespie, P.E. Parsons, J.S. Waegener, D.W.H. 
Riches, and F.J. Accurso. 1995. Airway inflammation in infants with cystic fibrosis can occur in the absence of detectable endotoxin in bronchoalveolar lavage fluid. Am. J. Respir. Crit. Care Med. 151:247a. (Abstr.)

11. Feldman, M., R. Bryan, S. Rajan, L. Scheffler, S. Brunnert, H. Tang, and A. Prince. 1998. The role of flagella in pathogenesis of Pseudomonas aeruginosa pulmonary infection. Infect. Immun. 66:43-51.

12. Immundo, L., J. Barasch, A. Prince, and Q. Al-Awqati. 1995. CF epithelial cells have a receptor for pathogenic bacteria on their apical surface. Proc. Nat. Acad. Sci. USA. 92:3019-3023.

13. de Bentzmann, S., P. Roger, F. Dupuit, O. Bajolet-Laudinat, C. Fuchley, M. Plotkowski, and E. Puchelle. 1996. AsialoGm1 is a receptor for Pseudomonas aeruginosa adherence to regenerating respiratory epithelial cells. Infect. Immun. 64:1582-1588.

14. Yasumoto, K., S. Okamoto, N. Mukaida, S. Murakami, M. Mai, and K. Matsushima. 1992. Tumor necrosis factor- $\alpha$ and interferon- $\gamma$ synergistically induce interleukin 8 production in a human gastric cancer cell line through acting concurrently on AP-1 and NF-кB-like binding sites on the interleukin 8 gene.J. Biol. Chem. 267:22506-22511.

15. Kunsch, C., and C.A. Rosen. 1993. NF-кB subunit-specific regulation of the interleukin-8 promoter. Mol. Cell. Biol. 13:6137-6146.

16. Baldwin, A.S., Jr. 1996. The NF-кB and Ік $\beta$ proteins: new discoveries and insights. Annu. Rev. Immunol. 14:649-681.

17. Sovak, M.A., R.E. Bellas, D.W. Kim, G.J. Zanieski, A.E. Rogers, A.M. Traish, and G.E. Sonenshein. 1997. Aberrant nuclear factor-кB/Rel expression and the pathogenesis of breast cancer. J. Clin. Invest. 100:2952-2960.

18. Bargou, R.C., F. Emmerich, D. Krappmann, K. Bommert, M.Y. Mapara, W. Arnold, H.D. Royer, E. Grinstein, A. Greiner, C. Scheidereit, et al. 1997. Constitutive nuclear factor-кB-RelA activation is required for proliferation and survival of Hodgkin's disease tumor cells. J. Clin. Invest. 100:29612969.

19. Bauerle, P.A., and D. Baltimore. 1996. NF-кB: Ten years after. Cell. 87: $13-20$

20. Pahl, H.L., M. Sester, H.-G. Burgert, and P.A. Bauerle. 1996. Activation of the transcription factor NF-кB by the adenovirus E3/19K protein requires its ER retention. J. Cell Biol. 132:511-522.

21. Grunert, D.C., C.B. Basbaum, M.J. Welsh, W.E. Finkbeiner, and J.A. Nadel. 1988. Characterization of human tracheal epithelial cells transformed by an origin defection simian virus 40. Proc. Natl. Acad. Sci. USA. 85:5951-5955.

22. Kunzelmann, K., E.M. Schwiebert, P.L. Zeitlin, W.L. Kuo, B.A. Stanton, and D.C. Grunert. 1993. An immortalized cystic fibrosis tracheal epithelial cell line homozygous for the delta F508 mutation. Am. J. Respir. Cell Mol. Biol. $8: 522-529$.

23. Cozens, A.I., M.J. Yezzi, K. Kunzelmann, T. Ohrui, L. Chink, K. Eng, W.E. Finkbeiner, J.H. Widdecombe, and D.C. Gruenert. 1994. CFTR expression and chloride secretion in polarized immortal human bronchial epithelial cells. Am. J. Respir. Cell Mol. Biol. 10:38-47.

24. Ma, J., J. Tasch, T. Tao, J. Zhao, J. Xie, M.L. Drumm, and P.B. Davis. 1996. Phosphorylation-dependent block of cystic fibrosis transmembrane conductance regulator chloride channel by exogenous $\mathrm{R}$ domain protein. J. Biol. Chem. 271:7351-7356.

25. Zeitlin, P.L., L. Lu, G. Cutting, G. Stetten, K.A. Kieffer, R. Craig, and W.B. Guggino. 1991. A cystic fibrosis bronchial epithelial cell line: immortalization by adeno-12-SV40 infection. Am. J. Respir. Cell Mol. Biol. 4:313-319.

26. Saiman, L., G. Cacalano, and A. Prince. 1990. Pseudomonas cepacia adherence to respiratory epithelial cells is enhanced by Pseudomonas aeruginosa. Infect. Immun. 58:2578-2584.

27. Dignam, J.D., R.M. Lebovitz, and R.G. Roeder. 1983. Accurate transcription initiation by RNA polymerase II in a soluble extract from isolated mammalian nuclei. Nucl. Acids Res. 11:1475-1489.

28. Henderson, A.J., X. Zou, and K.L. Calame. 1995. C/EBP proteins activate transcription from the human immunodeficiency virus type 1 long terminal repeat in macrophages/monocytes. J. Virol. 69:5337-5344.

29. Muller, J.M., H.W. Ziegler-Heitbrock, and P.A. Bauerle. 1993. Nuclear factor-кB, a mediator of lipopolysaccharide effects. Immunobiology. 18:233256

30. Joseph, C.K., S.D. Wright, W.G. Bornmann, J.T. Randolph, E.R. Kumar, R. Bittman, J. Liu, and R.N. Kolesnick. 1994. Bacterial lipopolysaccharide has structural similarity to ceramide and stimulates ceramide-activated protein kinase in myeloid cells. J. Biol. Chem. 269:17606-17610.

31. Pier, G.B., M. Grout, and T.S. Zaidi. 1997. Cystic fibrosis transmembrane conductance regulator is an epithelial cell receptor for clearance of Pseudomonas aeruginosa from the lung. Proc. Natl. Acad. Sci. USA. 94:1208812093.

32. Henkel, T., T. Machleidt, I. Alkalay, M. Kronke, Y. Ben-Neriah, and P. Bauerle. 1993. Rapid proteolysis of $\mathrm{I}_{\kappa} \mathrm{B}-\alpha$ is necessary for activation of transcription factor NF-кB. Nature. 365:182-185.

33. Scheinman, R.I., P.C. Cogswell, A.K. Lofquist, and A.S. Baldwin. 1995. Role of transcription factor IкB- $\alpha$ in mediation of immunosuppression by glucocorticoids. Science. 270:283-286.

34. Auphan, N.J., A. DiDonato, C. Rosette, A. Helmberg, and M. Karin. 1995. Immunosuppression by glucocorticoids: inhibition of NF-kB activity through induction of IкB synthesis. Science. 270:286-290.

35. DeBosscher, K., M.L. Schmitz, W. van den Berghe, S. Plaisance, W. Fiers, and G. Hageman. 1997. Glucocorticoid-mediated repression of nuclear factor-кB-dependent transcription involves direct interference with transactivation. Proc. Natl. Acad. Sci. USA. 94:13504-14509.

36. Denning, G.M., M.P. Anderson, J.F. Amara, J. Marshall, A.E. Smith, and M.J. Welsh. 1992. Processing of mutant cystic fibrosis transmembrane conductance regulator is temperature-sensitive. Nature (Lond.). 358:761-764.

37. Magalini, A., G. Savoldi, F. Ferrari, M. Garnier, P. Ghezzi, A. Albertini, and D. DiLorenzo. 1995. Role of IL-1 $\beta$ and corticosteroids in the regulation of the $\mathrm{C} / \mathrm{EBP}-\alpha, \beta$ and $\delta$ genes in vivo. Cytokine. 7:753-758.

38. Kagnoff, M.F., and L. Eckmann. 1997. Epithelial cells as sensors for microbial infection. J. Clin. Invest. 100:6-10.

39. DiMango, E., R. Bryan, and A. Prince. 1996. Epithelial ingestion of Pseudomonas aeruginosa: a comparison of CF and normal cells in primary culture and transformed cell lines. Pediatr. Pulmonol. 13(Suppl.):287a. (Abstr.)

40. Naumann, M., S. Webler, C. Rartsch, B. Wieland, and T.F. Meyer. 1997. Neisseria gonorrhoeae epithelial cell interaction leads to the activation of the transcription factors nuclear factor $\mathrm{\kappa B}$ and activator protein 1 and the induction of inflammatory cytokines. J. Exp. Med. 186:247-258.

41. Hedlund, M., M. Svensson, A. Nilsson, R.-D. Duan, and C. Svanborg. 1996. Role of the ceramide-signaling pathway in cytokine responses to P-fimbriated Escherichia coli. J. Exp. Med. 183:1037-1044.

42. Li, J.-D., A.F. Dohrman, M. Gallup, S. Miyata, J.R. Gum, Y.S. Kim, J.A. Nadel, A. Prince, and C.B. Basbaum. 1997. Transcriptional activation of mucin by Pseudomonas aeruginosa lipopolysaccharide in the pathogenesis of cystic fibrosis lung disease. Proc. Natl. Acad. Sci. USA. 94:967-972.

43. Huwiler, A., J. Brunner, R. Hummel, M. Vervoordeldonk, S. Stabel, H. Van den Bosch, and J. Pfeilschifter. 1996. Ceramide binding and activation defines protein kinase c-Raf as a ceramide-activated protein kinase. Proc. Natl. Acad. Sci. USA. 93:6959-6963.

44. Van Heeckeren, A., R. Walenga, M.W. Konstan, T. Bonfield, P.B. Davis, and T. Ferkol. 1997. Excessive inflammatory response of cystic fibrosis mice to bronchopulmonary infection with Pseudomonas aeruginosa. J. Clin. Invest. 100:2810-2815. 